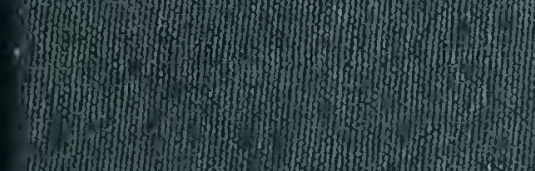

30.

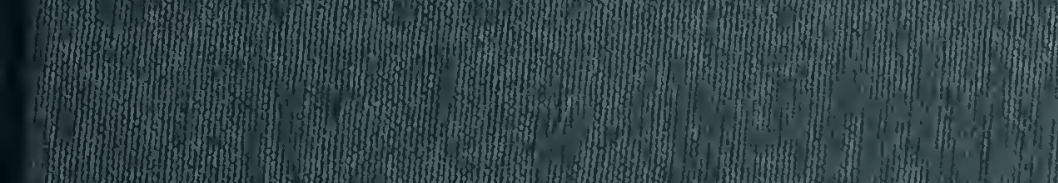

,

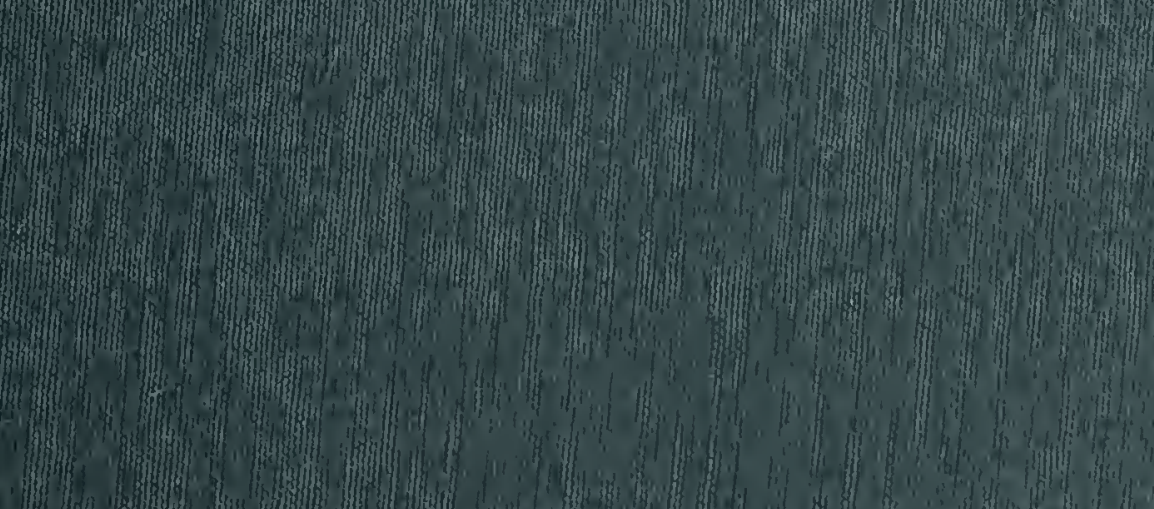

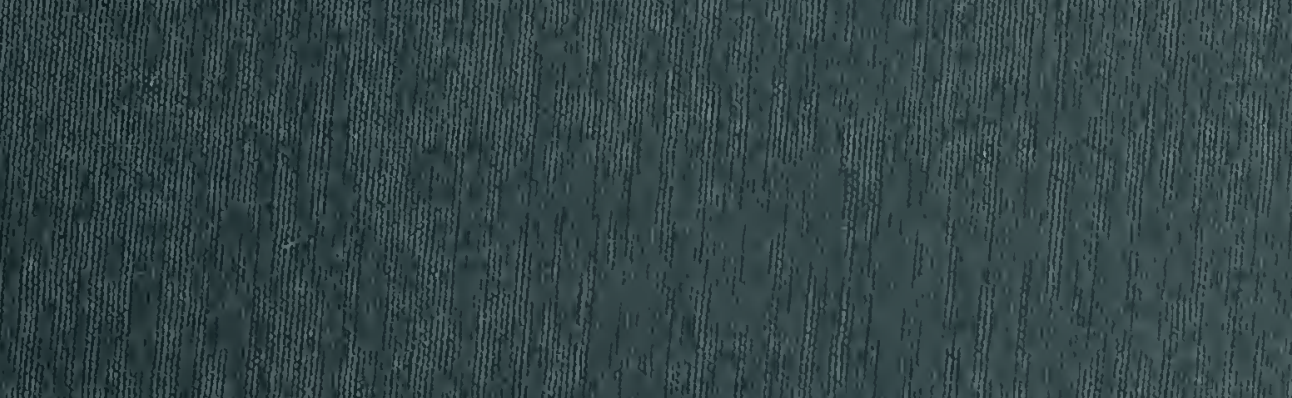

)

(1)

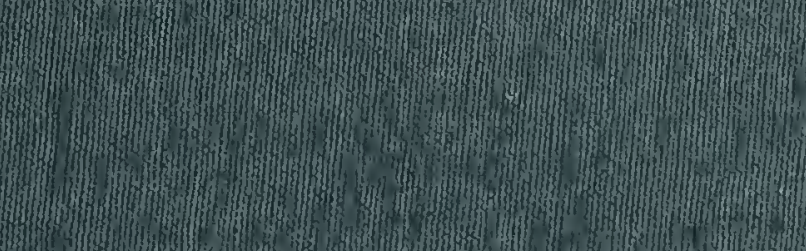

(1)

m.m

4-2 H.m 


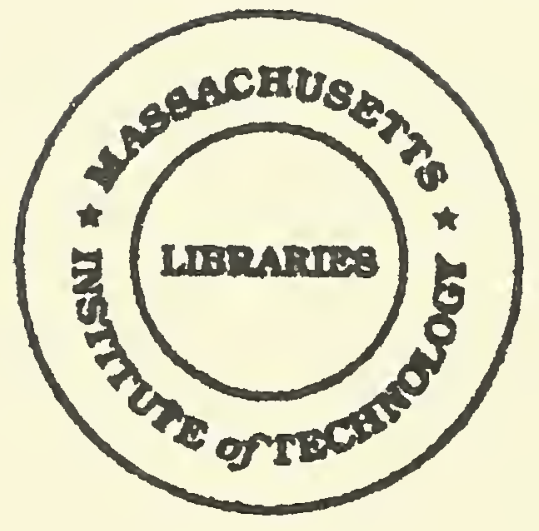


Digitized by the Internet Archive in 2011 with funding from Boston Library Consortium Member Libraries

http://www.archive.org/details/laborsupplyofear00temi 
Massachusetts Institute of Technology

Department of Economics

Working Paper Series

\author{
THE LABOR SUPPLY OF \\ THE EARLY ROMAN EMPIRE
}

Peter Temin

Working Paper 01-45

November 2001

Room E52-251
50 Memorial Drive
Cambridge, MA 02142

This paper can be downloaded without charge from the Social Science Research Network Paper Collection at http://papers.ssm.com/paper.taf?abstract_id $=x x x x x$ 



\title{
The Labor Supply of the Early Roman Empire
}

\author{
Peter Temin
}

06 December 2001

\begin{abstract}
I argue that it makes sense to speak of a functioning labor market in the early Roman Empire where the supply and demand for labor were equilibrated by wages and other payments to workers, albeit in a rough way. The economy of the early Roman Empire therefore had a market in this critical factor of production that resembles the labor market in more recent market economies. Slaves were included in the general labor market because Roman slavery was very different from modern slavery in the Americas. In the early Roman Empire, frequent manumission provided incentives for slaves to cooperate with their owners and act like free laborers.
\end{abstract}

My thanks for help and advice from Roger Bagnall, Alan Bowman, Richard DuncanJones, Peter Garnsey, Keith Hopkins, Dominic Rathbone, and Joshua Sosin. I also thank the Warden and Fellows of Nuffield College, Oxford, for research support. All errors remain mine alone. 


\section{The Labor Supply of the Early Roman Empire}

Ancient Rome was a slave society. This view has become so common as to need no citation, although Moses Finley may have been the first to assert that Rome was one of only five slave societies in recorded history (Finley, 1980). This characterization is important because slavery is used as a sign of a non-market economy. This in turn is a classification within the Gemeinschaft und Gesellschaft conception of history as the account of progress from one to the other. The former is the informal economy of families and villages where social rules and obligations are dominant influences on behavior. The latter is the market economy characteristic of modern, urban societies. In the classic view of Toennies, "a period of Gesellschaft follows a period of Gemeinschaft (Toennies, 1887, 231)." Toennies, citing Marx, described the mechanism behind this progress "as a process of increasing urbanization (Toennies, 1887, 233)." Marx and Toennies were trying to make sense of the changes they were experiencing in nineteenthcentury society, in which the dramatic rise of urbanization loomed large.

Polanyi, in The Great Transformation, located the center of this transition in the labor market. He argued that labor markets in the modern sense did not exist before the Industrial Revolution and the Poor Laws that accompanied it in England (Polanyi, 1944). This view is consonant with Weber's judgment that a critical component of capitalism was free labor (Weber, 1905). If one way to identify a period of Gesellschaft is the prevalence of urban life, an even more important key is the presence of a labor market in 
which the services of labor can be bought and sold, which Polanyi argued came about only two centuries ago.

The wide use of slavery in Rome is taken as a sign that Gemeinschaft dominated the life of the Roman Republic and the Early Roman Empire. I argue here that this view is mistaken. In fact, Roman slavery was so different from modern slavery that it did not indicate the presence of non-market, traditional actions. Instead, ancient Roman slavery was an integral part of a labor force sharing many characteristics with the labor force of other advanced agricultural societies. Finley asserted, by contrast, "In early societies, free hired labour (though widely documented) was spasmodic, casual, marginal. .. [A]ncient slavery ... co-existed with other forms of dependent labour, not with free wage-labour (Finley, 1980,pp. 68, 127)." l argue here that free hired labor was wide-spread and that ancient slavery was part of a unified labor force in the early Roman Empire.

Anthropologists distinguish between open and closed models of slavery. Open slavery is a system in which slaves can be freed and accepted fully into general society; closed slavery is a system in which slaves are a separate group so that they are not accepted into general society even if occasionally freed. Roman slavery conformed to the open model. By contrast, "American slavery [was] perhaps the most closed and castelike of any [slave] system known (Watson, 1980, p. 7)." I argue that this difference placed Roman slaves in a very different position relative to other workers than that

\footnotetext{
${ }^{1}$ More recent views reject the opposition of Gemeinschaft and Gesellschaft in favor of a more complex view that sees both ideal types as present in a wide variely of socielies. In this view, which derives also from Toennies, the question is which form of society is dominant, not ubiquitous. History then becomes an account of the shifting balance between Gemeinschaft and Gesellschaft rather than the story of a total transition from one to the other (Bender, I978). One might regard any society as dominated by one mode, but the sense that progress has eliminated Gemeinschaft is gone.
} 
occupied by modern slaves. The open system of Roman slavery made slaves full participants in the labor market of the early Roman Empire.

Manumission, a distinguishing feature of Roman slavery, was key. Slaves in the early Roman Empire could anticipate freedom if they worked hard and demonstrated skill. Once freed, they were accepted into Roman society far more completely than the freedmen in other closed systems of slavery. The promise of manumission of course was most apparent for urban, skilled, literate slaves, but it pervaded Roman society. The incentive effect of possible manumission made Roman slaves into members of a unified labor force in the early Roman Empire.

Examining free labor, the evidence on wage dispersion in the early Roman Empire is indistinguishable from that in pre-industrial Europe, although our knowledge of ancient wage rates is sparse. Turning to slaves, the open system of Roman slavery differed dramatically from the closed system of slavery in the Americas. Roman slaves were manumitted with great frequency, and freedmen were accepted into Roman society. Roman slaves, seeking freedom rather than rebellion, were educated and held a wide variety of jobs as a result. All of these conditions were fundamentally different from those in the Southern United States and in Latin America. Modern American slaves were not part of the general labor force, while Roman slaves were.

The paper is organized in a series of steps. I first discuss the supply of labor in Roman Italy and Egypt and discuss its relation to a labor market. I then compare slavery in the early Roman Empire to modern slavery and related institutions, and I outline its history. Finally, I test the propositions asserted earlier with a comparison of ancient and early modern labor conditions. I compare slavery in the early Roman Empire to that in 
$19^{\text {th }}$ century America and wage dispersion in the early Roman Empire to that in early modern Europe.

\section{The Roman Labor Supply}

We can speak of a labor supply if there is labor demand and a labor market where the two are brought together. To have a labor market, two conditions must be filled, at least partially. Workers must be free to change their economic activity and/or their location, and they must be paid something like their labor productivity to indicate to them which kind of work to choose. ${ }^{2}$ How closely do these conditions need to be filled to speak of a unified labor market? The answer for contemporary studies is that labor needs to be mobile enough to bring wages for work of equal skill near equality. That does not mean that everyone changes jobs with great frequency; it does mean that enough people are able and willing to do so to eliminate conditions where payments to labor are either excessively higher or lower than the wages of comparable work in other locations or activities. Even in the United States today, which contains the most flexible labor market in history, wages for comparable jobs are not completely equalized across the country. ${ }^{3}$

There is no labor market, or perhaps only local, isolated labor markets, when these conditions are not fulfilled. People might not be able to change their economic activities due to hereditary or guild restrictions. They might be restricted in what they could earn or entitled to income for reasons unrelated to their work. Wages, in the sense of a return for labor services rendered, might be "spasmodic, casual, marginal." The

\footnotetext{
${ }^{2}$ Labor productivity here means the output of goods or services that results from the employment of this worker. It is not the average labor productivity of all workers, but the productivity of the worker in question. In economics jargon, it is the marginal product of labor.
} 
choice between these two alternatives is important because the nature of the labor market is an important component to the nature of the economy as a whole. If there is a unified labor market, then the economy can respond to external influences in the way of the market economies so familiar to us today. If there is a technical change that makes one activity more profitable or a new discovery that provides an economic opportunity in a new place, then labor can move to take advantage of these new opportunities. If, however, there were not a unified labor market, only local or non-existent labor markets, then the economy would not be able to respond to changes in the external environment. The economy instead would continue to act in traditional ways, perhaps with a small gesture toward the new opportunities. There would be no way to attract enough workers to the new activity or site to exploit the new opportunity fully. The economy would be dominated by Gemeinschaft, not Gesellschaft.

The task of distinguishing these two conditions in the early Roman Empire is rendered difficult, as always, by the absence of comprehensive evidence. The chief evidence for the absence of a labor market in the early Roman Empire has been the presence of slaves, and I will focus my attention on them. The question is not how many slaves were present, but rather how slavery operated. Slaves in the American South before the Civil War were not part of a unified American labor market because their activities and incomes were so restricted that they had no incentive to seek better working conditions. I argue that slaves in the early Roman Empire did not suffer under the same restrictions. I also argue that free hired labor was the rule rather than the exception in the rest of the early Roman Empire.

\footnotetext{
3 "There exist sizable wage differences across regions or states in the United States, even for workers with particular skills looking for similar jobs (Borhas, 2001, 71)."
} 
The abstract conditions that define a labor market typically are related to labor markets in industrial economies; they need modification to apply to labor markets in agricultural economies. Most workers in such an economy are rural, working either in agriculture or in associated crafts and services. Most of them will not change their occupation or their residence without strong pressure of some sort. A rural labor market exists when enough of them are free to move in response to economic stimuli to keep rural wages at a moderately uniform level. As will be documented below, this still allows for substantial geographic variation in both the level and the rate of change of rural wages. For example, migration and wages interacted in early-modern Britain to keep wages similar, but by no means equal.

One possible move in advanced agricultural economies is to a city, and this change must be included in the range of possibility for a substantial fraction of rural workers. It is rare, both in history and among current agricultural economies, for rural and urban wages to be equalized by migration. Economists do not regard this discrepancy as negating the existence of a unified labor market; they instead explain the difference by noting that new urban workers often are unemployed and that only the expected wage (that is, the wage times the probability of earning it) should be equalized by migration. Living costs also typically are higher in cities, and urban wages may exceed rural wages for this reason as well. Urban wages that are double rural wages do not strain the ability of these factors to account for the discrepancy (Harris and Todaro, 1970).

Wages vary in a labor market by skill as well as by location. Almost all workers have skills, basic skills of agriculture and often more advanced skills as well. Economists 
call these skills human capital. Most ancient workers had few skills, that is, very little human capital. They could not read, and they knew little of value in a skilled activity. Craftsmen and some agricultural workers of course had traditional skills that did not depend on literacy, and they would receive a higher wage in a rural labor market for utilizing these skills. Agricultural workers probably would not be compensated for these skills in urban areas, since they did not possess human capital that could be used in a city. Fewer workers were literate and even fewer highly skilled as well. We tend to know more about these workers than about the less skilled workers because of the literary bias of our sources. But we must remember that the great mass of workers in the early Roman Empire were illiterate and unskilled.

The conditions for the existence of a labor market typical of a market-based agricultural economy were satisfied in the early Roman Empire, although with less mobility and less correspondence between wages and labor productivity than one finds in Europe today. In other words, there was a market economy, but it did not operate with the efficiency of a modern market economy. The labor market in the early Roman Empire was comparable to the labor markets of early modern Europe-more efficient in some ways and less efficient in other ways.

Free urban workers in the early Roman Empire were compensated for their work and were able to change their economic activities. There were no hereditary or guild barriers to overcome. Workers in large organizations like mines and galley ships, were paid wages, as in more modern labor markets. People engaged in more skilled and complex tasks were paid in more complex ways, most probably for longer units of time than wage labor, again as in more modern labor markets, even though explicit long-term 
contracts for labor were not made. It is reasonable that the force of competition under those circumstances brought wages and labor productivity into the same ballpark. Skilled workers in were paid more than those engaged in unskilled tasks. Educated workers received higher wages than uneducated. Administrators of large organizations earned more than individual workers. There is abundant evidence on this point.

Some work in the early Roman Empire was done for wages and some by slaves. There were even salaried long-term free workers in Egypt under the early Roman Empire (Rathbone, 1991, 91-147). Craftsmen sold their wares in cities and also supplied them to rural and urban patrons in return for long-term economic and social support. People who worked for or supplied senators and equestrians similarly often worked for long-term rewards and advancement. Free workers, freedmen, and slaves worked in all kinds of activities, and contemporaries saw the ranges of jobs and of freedom as quite separateeven orthogonal. In particular, rural slaves hardly were all undifferentiated gang laborers; there are lists of rural slave jobs that are as varied as the known range of urban or household slave jobs (Bradley, 1994, 59-65). Cicero (de Officiis, 1.150-1), anticipating Marx, conflated legal and economic relations by equating wages with servitude.

The army must be distinguished from private activities, as it must in modern economies. Peacetime armies often are voluntary, recruited the way any large organization recruits workers, by offering favourable wages and working conditions. Wartime armies by contrast typically are staffed by conscription, which is a non-market process. Actions within armies are directed by commands, not by market transactions. Armies therefore represent at best a partial approximation to a free labor market and 
typically an exception to it. Since armies unhappily are present in almost all societies, we place this exception to the general rule to one side.

The wages of the Roman army stayed constant for many decades at a time. It was staffed by a mixture of attraction and conscription (Brunt, 1974). When the army was not fighting, which was most of the time, soldiers had to be set tasks to keep them fit and out of trouble. They were used to build roads and public monuments near where they were stationed. This construction activity did not interfere with the labor market in Rome or elsewhere in the center of the empire since the army was stationed at the frontiers (Watson, 1969, 45).

Slaves appear to be like armies with activities directed by commands and disobedience punished severely. But this is inaccurate for slavery in the early Roman Empire, strongly in cities and less so in rural areas, even though it may describe modern slavery. Ancient Roman slavery was not like modern slavery, and it did not depend primarily on the threat of punishment to motivate slaves. It was open rather than closed slavery, and freedmen moved into the mainstream of Roman economic activity. As a result, slaves were able to participate in the labor market of the early Roman Empire in almost the same way as free laborers, although their starting point often was considerably less favourable.

In other words, slaves participated in the meritocratic process of advancement in the early Roman Empire. They started from a low place-the bottom only if they lacked education-but they did not need to remain there. Freedmen started from a better position, and their ability to progress was almost limitless, despite the existence of some 
prominent restrictions. These conditions created powerful positive incentives for slaves in the early Roman Empire. ${ }^{4}$ These assertions are explicated below.

\section{Roman Slavery}

Few people would choose to be a slave: almost all Roman slaves were forced into slavery as captives, children of slaves, abandoned children, or debt bondage. It was bad to be a slave in the early Roman Empire, as it has been bad to be a slave throughout history. A Roman slave was subject to the cruelty endemic in the early Roman Empire with far less protection than free people; a person who found himself or herself in slavery had drawn a poor hand from the deck of life. This is without doubt. But even if slaves were at or near the bottom of society and the economy, it makes sense to ask how hopeless was their position. Slaves were unfortunate people, but they were still people.

All people, even slaves, need to have incentives to do their work. Free people may work to increase their income. If slaves cannot legally lay claim to the fruits of their labor, other incentives must be constructed. These incentives may be classified as positive (rewards for hard or good work) or carrots and negative (punishment for slacking off or not cooperating) or sticks. There is a large literature on the incentive structures of modern American slavery, possibly because the high emotional content of this literature makes consensus elusive. But while disagreements remain on many points, there is agreement that negative incentives, that is, punishments and sanctions, dominated the lives of modern slaves in the Americas.

\footnotetext{
"Compare Gibbon's magisterial pronouncement early in The Decline and Fall of the Roman Empire: "Hope, the best comfort of our imperfect condition, was not denied to the Roman slave; and if he had any opportunity of rendering himself either useful or agreeable, he might very naturally expect that the
} 
By contrast, positive incentives were more important than negative in motivating Roman slaves. Sticks can get people to work, but not to do skilled tasks that require independent work (Fenoaltea, 1984). If it is hard to distinguish poor performance from bad luck when work is complex, carrots are far more effective than sticks in motivating hard work. Consider a managerial job, like a vilicus. A slave in such a position motivated by negative incentives could claim that any adverse outcomes were the result of bad luck, not his actions. Beating him or exacting worse punishment would lead to resentment rather than cooperation and-one confidently could expect-more "bad luck." A vilicus motivated by positive incentives would anticipate sharing in any "good luck"; he would work to make it happen. Contrast this example with that of an ordinary field hand. His effort could be observed directly and easily; slackers could be punished straight away. Since field hands typically work in a group, positive incentives that motivate individuals to better efforts are hard to design.

There was cruelty in ancient slavery, as there was in early modern indenture. It has been described often because it contrasts sharply with our modern sense of individual autonomy. But cruelty was a hallmark of the early Roman Empire as it has been of most non-industrial societies. Imperial Rome in fact appeared to celebrate cruelty more than usual as an offshoot of its military orientation; ancient cruelty was by no means reserved for slaves. The vivid examples of violence toward slaves do not make the case that 
cruelty dominated the lives of slaves since we also have many competing stories of more benevolent slave conditions. ${ }^{5}$

Similarly, the miserable condition of slaves working in the bakery overseen by Apuleius' golden ass (Golden Ass, 9.2) do not illustrate the harsh conditions of Roman slavery, but rather the dismal conditions of ordinary labor in pre-industrial economies. In these Malthusian economies, greater productivity resulted in larger populations rather than gains in working conditions or real wages. Almost all workers before the Industrial Revolution and the Demographic Transition lived near what economists call subsistence. This does not necessarily mean the edge of starvation, but it often means people working to the limit of their endurance. And work in a small bakery was and is very hard, long and hot, even today.

For some poor people, the life of a slave appeared better than that of a free man. Ambitious poor people sold themselves into slavery in a concrete realization of Hicks' long-term employment contract that promised, however uncertainly, more advancement than the life of the free poor (Ramin and Veyne, 1981). ${ }^{6}$ This action, however rare in the early Roman Empire, would have been inconceivable in a closed system of slavery system built on negative incentives.

It is necessary to distinguish between rural and urban conditions when evaluating the balance between positive and negative incentives. Rural slaves in antiquity were those slaves most like modern slaves; they performed work that was easily supervised

\footnotetext{
${ }^{5}$ Slave revolts also do not give evidence of predominantly negative incentives. The attested slave revolts all were concentrated in a short span of time in the late Republic, a time of great social upheaval. See Bradley (1989).

6 "ll arrivait que des adolescents ambitieux choisissent la carrière d'esclave, qui, loute incertaine qu'elle étail, offrait quelque chance de promotion, alors que la pauvrelé libre n'en offrait aucune (Ramin and Veyne, 1981, p. 496)."
} 
and were subject to negative and even cruel incentives. Urban slaves in the early Roman Empire, which have no modern counterpart, were in a different position. ${ }^{7}$ They are the main focus of this discussion, since their conditions have not been understood. We do not know how large a share of Roman slaves were urban. It was a substantial fraction, even possibly reaching half at some times.

Conventional estimates place the population of Italy in the Principate around six million with one million of them living in Rome itself. Slaves are estimated to make up one-third of the population of Italy and up to one-half of the population of Rome (Hopkins, 1978, 101). These estimates imply that one quarter or less of the Italian slaves lived in Rome, while the rest lived in smaller cities and the countryside-where they were less than one-third of the rural labor force. If these extimates are even approximately correct, slaves were not the dominant labor force either in the city or the countryside of the early Roman Empire. Slaves in Egypt appear from surviving census returns to have composed about ten percent of the population, spread among households that each held very few slaves. As two-thirds of the listed slaves were women, they appear to have been household rather than agricultural workers (Bagnall and Frier, 1994, 48-49, 71). All of these educated guesses are highly uncertain (Scheidel, 2001, 49-61). Manumission into Roman citizenship played an important part in urban Roman slaves' incentives and perhaps also in some rural slaves' incentives. It is the key element that defined slavery in the early Roman Empire, and it reveals the open nature of Roman slavery. Manumission was common, but not universal. There were no rules determining

\footnotetext{
${ }^{7}$ Rio de Janeiro in the early $19^{\text {th }}$ century provides a partial parallel, with 80,000 slaves in a total urban population of 200,000 in 1849. But this modern example exposes the uniqueness of ancient Rome (and perhaps other ancient cities as well) because the prevalence of slaves in Rio was very short-lived, the slaves there were almost all unskilled, and Rio was a city at the fringe of market activity. See Karasch, 1987.
} 
who would be freed, but more cooperative and productive slaves had the best chance for manumission. In particular, slaves often were able to purchase freedom if they could earn the necessary funds in a peculium, which served as a tangible measure of slave productivity. The right of slaves to accumulate and retain assets was an important part of the incentive structure of slaves. If a slave was sold or freed, he kept his peculium, even though slaves technically could not own property (Crook, 1967, 187-91). Of course if a slave used his peculium to purchase his freedom, his former owner acquired possession of the slave's earnings. Slaves even owned slaves. There was nothing like the peculium in modern slavery. ${ }^{8}$

Hopkins (1978, 115-32) asked, "Why did Roman masters free so many slaves?" His answer was complex. On one hand, he noted that the promise of freedom was a powerful incentive: "The slave's desire to buy his freedom was the master's protection against laziness and shoddy work." He distinguished Roman slavery from that in the southern United States. On the other hand, however, he emphasized the similarity of these two types of slavery and emphasized the role of cruelty and negative incentives. He devoted more space to slave resistance and rebellions than to slave achievement and cooperation. He argued that the apparent sharp line between slavery and freedom in fact was part of a continuum of labor conditions, but he failed to break away from the view of American slavery being formulated at the time he wrote. This imperfect analogy still dominates the field (Bradley, 1994).

Garnsey $(1996,87)$ argued that ancient slavery was less harsh than slavery in the southern United States. This judgment, however, was placed late in a book of intellectual

\footnotetext{
${ }^{8}$ Again, Rio offers a partial exceplion, where some slaves could earn enough to purchase their wives" freedom, although typically not enough to obtain their own (Karasch, 1987).
} 
history that stretched from Greeks to Christians, and Roman slavery as a distinct labor system was not emphasized. Garnsey $(1996,97)$ noted that, "The prospect of manumission gave [Roman] slaves an incentive to work and behave well." He drew out the implications of this proposition for the idea of slavery, particularly among Christians. This paper draws implications for the economic role of Roman slavery in the Roman . labor force. ${ }^{9}$

Bradley (1987) devoted a chapter in his study of Roman slavery to manumission, but he minimized its role as an incentive. He described manumission as bribery and as social manipulation, confirming his overall judgment that, "the Roman slavery system was by nature oppressive and was maintained for the benefit of the privileged only (Bradley, 1987, 19-20)." He seemed to view Roman slavery as a closed system where slaves and freedmen remained socially distinct from the free population, a presumption made explicit in his later book comparing ancient and modern slavery (Bradley 1994).

In addition to buying freedom, some valuable Roman slaves were freed without payment. This might be a reward for more complex achievement, or it could be for noneconomic reasons. This incentive mechanism therefore operated with considerable uncertainty. That made manumission in the early Roman Empire a bit like speculating with a new company today. Success is a product of both skill and luck, and the latter can be the more important. Of course, success only comes to those that try, that is, those people who are willing to take the risks present in any start-up company. And there does not seem to be a shortage of people willing to take such risks today. Manumission represented the same kind of opportunity for Roman slaves. If a slave tried, both skill

\footnotetext{
${ }^{9}$ Findlay (1975) derived the oplimal timing of manumission for a profit-maximizing owner.
} 
and luck would play a part in his eventual success or failure. But we should not think that the risks of the process discouraged many slaves. ${ }^{10}$

Some Roman slaves were educated, and even educated people sometimes had the bad luck to be enslaved. Hereditary slaves in cities often received education as well. There was no prohibition against educating slaves as there was in modern slavery. Modern slave owners relied on negative incentives and were afraid of slave revolts led by educated slaves. Ancient slave owners used positive incentives and allowed and even encouraged slaves to be educated and perform responsible economic roles.

Freedmen were accepted into free society on an almost equal basis, that is, they were granted Roman citizenship. The well-known association of freedmen with former masters worked to their mutual benefit. Information was scarce in the early Roman Empire. When people engaged in trade or made arrangements for production, they needed to know with whom they were dealing. Roman society was divided into families which provided some identification for individuals. Slaves retained the names of and connections with their former owners and therefore could be identified as members of their owners' family (e.g., Garnsey, 1998, 30-37). This identification helped the former slave to operate in the economy, and a productive freedman returned the favor by increasing the reputation of his former owner and his family. Freedmen of course could marry other Roman citizens, and children of freedmen (who were free) were accepted fully into Roman society.

\footnotetext{
${ }^{10}$ One way to see this paper is as an expansion of remarks in A Theory of Economic History by J. R. Hicks, a Nobel Laureare in Economics who was interested in history as well as iheory. Hicks argued, "There are two ways in which labour may be an article of trade. Either the labourer may be sold outright, which is slavery; or his services only may be hired, which is wage-payment (Hicks, 1969, 123)." Hicks acknowledged that slavery typically is a cruel, brutal institution, but he softened this indictment when slaves have personal relations with their owners and can take economic actions on their own, as he said
} 
Why did so many freedmen identify themselves as such on their tombstones? ${ }^{11}$ It does not seem like something to be proud of in the traditional view of Roman slavery. But if manumission was an incentive, and freedmen were the people who had responded most ably to that incentive, then there is something to be proud of. A freedman was attractive to deal with or hire because he had shown ambition and ability to get freed. These qualities were something to be proud of, and freedmen should have been proclaiming them when they could. To identify yourself as a freedman was to show you had been, in modern parlance, a self-made man, not the recipient of inherited wealth. This opportunity is the hallmark of open slavery.

We can think about a continuum of incentives, from all negative, as in a Nazi concentration camp or the Soviet gulag, to all positive, as in a progressive school where no child is criticized and all children are winners. Most working conditions fall somewhere between these two extremes. Modern jobs clearly are near, but not at, the positive end; one can be fired or demoted for non-performance. American slavery was near the opposite end; the threat of punishment was ubiquitous, while rewards for good service were rare. Roman slavery, by contrast, was far closer to the positive end than this, although hardly as close as modern jobs. Rural, illiterate, unskilled slaves in the early Roman Empire may have experienced something like American slavery. Educated, urban slaves experienced something close to the working conditions of free men.

Comparisons with more modern institutions reached, the slave is only a semi-slave (Hicks, 1969, 126n)." 
The mobility of labor in pre-industrial Europe was quite free, but limited by the remnants of feudal societies. Class differences, educational differences rooted in class distinctions, and laws restricting job changes prevented full occupational mobility. These restrictions made labor markets in early modern Europe less efficient than that of the carly Roman Empire; improved transportation and communication made labor markets in England and Holland, at least, more efficient.

Modern slavery was vastly different from ancient slavery; it was a closed system. Modern New-World slaves came from another continent and would have been hard to integrate into American society under any circumstances. Freedmen in the Americas had only very limited opportunities. Their descendants still are not fully integrated into society and the economy in the United States, as is true to a lesser extent in other former slave-owning countries in the Americas. Manumission therefore could not serve as an effective incentive device. Slaves were not freed, and the positive incentives that could be used were limited as a result. American slavery therefore was based on negative incentives.

American slaves were not educated. In fact, it was illegal to educate them in the southern United States. They did not hold responsible or skilled jobs. They were used in manual work that did not require much skill and which could be supervised easily. There were few rewards for good work and many sanctions for bad or slow work. Unlike conditions in the early Roman Empire, there was strict separation between slaves and free people in work, living arrangements, and social contacts.

\footnotetext{
11 "Many freedmen are known from their names alone, but we know of so many of them because they wanted to memorialise their life and achievements in the same way as more august senators and knights, erecting tombstones that have survived until today (Taylor, 1961)."
} 
Ancient slavery had some attributes of another modern institution, indentured

service. Poor Englishmen who wanted to emigrate to North America in the $18^{\text {th }}$ century would indenture themselves to pay for their passage across the Atlantic. Not being able to pay up front, they mortgaged their future labor to pay for their passage. Indentures were for a fixed number of years, often fewer than five, and immigrants were able to resume life without stigma after their indenture was over. While indentured, however, the immigrants had their freedom to move, to choose occupations, or even to determine the particulars of their life severely circumscribed. They were, in a descriptive oxymoron, short-term slaves (Galenson, 1981).

Modern indentured servants were better off than ancient slaves. Indentured servants chose to be indentured, while almost all ancient slaves were slaves against their will. Indentured servants also could anticipate future freedom with certainty while ancient slaves only had a conditional expectation of freedom. They shared a condition in which positive incentives dominated negative ones, even though the source of these incentives differed. Roman slaves worked hard in the anticipation of freedom; indentured servants worked hard to establish their reputation when free. The analogy is illuminating but not exact.

\section{A Short History of Roman Slavery}

The Roman Republic expanded and conquered all sorts of places and took away what they could. They took almost everything that moved, inanimate (treasure) and animate. They did not take everything and make whole populations into slaves because they wanted conquered provinces to pay taxes. They made captives into slaves, as did all 
conquerors up to modern times. Since the Romans started their conquests with close neighbours, individual slaves were almost indistinguishable from their conquerors and then owners.

Any society with lots of slaves has to figure out how to control them. Romans quickly opted for positive incentives, making slavery temporary for some slaves. It was important to make manımission available only for some slaves and to keep the criteria for manumission informal. Manumitting all slaves is like not freeing any; there is no incentive effect for slaves. Nothing that a slave does affects his or her chance of becoming free. Romans created a formal procedure for manumission, but left substantial room for individual judgments and decisions. The effect was to give slave owners the authority to decide which slaves merited freedom. This created the incentive for slaves to cooperate and help their owners, as opposed to satisfying a less personal criterion.

It is of course hard to know how the early Romans started down this path. It was not by following the Greek example. Greek slaves were not freed with any frequency, and freed slaves did not become members of Greek society. They were in "a limbo world in which full political and economic membership of the community was denied them." Athenian citizenship was exclusive while Roman citizenship was inclusive, and this fundamental difference may have determined how slavery was interpreted in the two societies (Garnsey, 1996, 7). In any case, the prevalence and visibility of manumission among Roman slaves made Roman slavery far different than slavery in Athens. ${ }^{12}$

\footnotetext{
${ }^{12}$ A few older ancient historians noted the comparatively benign quality of ancient slavery, although without referring to manumission and without distinguishing between Greek and Roman slavery. If Greek slavery was more similar to Roman than to modern slavery without the incentives deriving from frequent manumission, then it would be interesling to explain how this condition came about. See Zimmern, 1909; Jones, 1956.
} 
Manumission of course created a new set of problems: what to do with freedmen? There were many debates about this question. The debates presupposed a fact of Roman economic life. Information about the people with whom anyone did business was scarce, and some way needed to be found to assure satisfactory completion of any transaction. This need was filled partially by identifying people as members of families, with an implicit guarantee of quality by other members of the family. Slaves, coming to freedom without a family, naturally associated with their former owners' familics.

By the time of the Principate it is likely that most slaves were slaves from infancy, either children of slaves or unwanted children of free parents, since there were fewer new captives (Scheidel, 1997; Harris, 1999). Rules for manumission became more explicit. Augustus restricted the proportion of slaves a slave-owner could manumit at his death in a law (lex Fufia Caninia) that preserved the structure of incentives by forcing owners to decide which of their slaves to set free. ${ }^{13}$ Rights of freedmen were expanded. The incentive for slaves to act well became clear. Freedmen moved into skilled and wellrewarded trades and other activities. Their children born after manumission moved into society as a whole.

There was good reason for slaves and owners to want slave children to get an education. Education increased the value of slave labor to the owner, and it increased the probability that a slave's children would be freed. Educated slaves had the skills to accumulate a peculium, and they would be good business associates of their former owner. Most freedmen worked in cities as places for commerce and for advancement.

\footnotetext{
${ }^{13}$ Bradley $(1994,10)$ asserted in addition that the intent of the law was to restrict manumission only to those slaves who had proved that they deserved freedom.
} 
Freedmen become ubiquitous in Roman administration, public and private. They ran large private enterprises, and they were active in the administration of the empire. Why were they so prominent in so many activities? The process of manumission separated more able and ambitious people from others. The prospect of manumission was an incentive for all slaves. But the most active, ambitious, educated, and able slaves were more likely to gain their freedom as a reward for good behavior or by purchase. Of course, the system did not work perfectly, and many slaves were freed for eleemosynary motives or at their owner's death. These random elements do not eliminate the signal that a freedman in general was someone who had accomplished a great deal already. It was good policy to deal with and hire freedmen. This statement refers to a free labor market and makes sense only if there was a functioning labor market.

Society became more rigid in the late empire; opportunities for advancement in urban activities diminished. The incentive of manumission diminished as a result, for the freedman did not have the opportunities previous open to him. Slavery became more problematical. It changed its form and began to evolve into a different institution.

\section{Evidence from Different Periods}

This section compares slavery in the early Roman Empire with slavery in the Americas and Roman wage data with wages in pre-industrial Europe. I compare the ancient and more modern economies in five dimensions: manumission, conditions of freedmen, education, occupations, and wage dispersion.

First, manumission, its extent and manner. This is the characteristic that identifies the kind of slavery. Manumission was common and well-known in the early Roman 
Empire. A well-known legend recounted how a slave was freed in the first year of the Republic, $509 \mathrm{BCE}$, as a reward for faithful service, albeit of a political rather than an economic nature (Livy, History, 2.3-5). A legal principle dealt with the status of the child of a slave woman who conceived, was freed, and then enslaved again before the birth of the child (Pauli Sententiae, 2.24.3). For this to be an interesting question, the boundary between slave and free must have been highly permeable.

There are no counts of Roman manumission, but the myriad references to manumission and freedmen in the surviving records attest to its frequency. Scheidel (1997) assumed that 10 percent of slaves in the early Roman Empire were freed every five years starting at age 25 in a demographic exercise. Some of his assumptions were challenged, but not this one (Harris, 1999). In the judgment of a modern observer, "Most urban slaves of average intelligence and application had a reasonable expectation of early manumission and often of continued association with their patron (Weaver, 1972, 1)." In the judgment of another, "Roman slavery, viewed as a legal institution, makes sense on the assumption that slaves could reasonably aspire to being freed, and hence to becoming Roman citizens (Watson 1987, 23)."

There were no male slaves in the Egyptian census over 32; since the census counted household slaves only, this age truncation suggests wide-spread manumission rather than exceptionally high slave mortality (Bagnall and Frier, 1994, 71, 342-43). Female slaves generally were freed if they had more than three children, which may not have been uncommon in an age without family planning (Columella, 1.8.19). ${ }^{14}$ Manumission on this scale must have been apparent to every slave, certainly to every 
urban slave, and a powerful incentive to cooperate with his or her master and to excel at any task in order to earn freedom.

Slave conditions in the southern United States were completely different.

Manumission was the exception rather than the rule; American slaves could not anticipate freedom with any confidence. ${ }^{15}$ Manumission required court action in Louisiana, an onerous process that left traces in the historical record. An exhaustive count of Louisiana manumission showed that the rate of manumission in the early 19th-century century was about one percent in each five-year period, an order of magnitude less than Scheidel assumed for the early Roman Empire. In addition many of those freed were children under ten, and the majority of the adults freed were women-presumably the children's mothers (Hall, 2000). ${ }^{16}$ Fogel and Engerman, champions of positive incentives in American slavery, reported even lower manumission rates at mid-century: "Census data indicate that in 1850 the rate of manumission rate was just 0.45 per thousand slaves (Fogel and Engerman, 1974, 150)." That is .045 per hundred slaves or 0.2 percent in a five-year period. American slaves, and particularly male slaves, had little anticipation of freedom and little incentive to cooperate in the hope of freedom.

Slaves in Brazil shared the same fate as those in the United States. Very few slaves were manumitted in Brazil. Although manumission began roughly at the outset of slavery, there were many legal and circumstantial barriers that prevented it from becoming widespread; only a miniscule number of Brazilian slaves ever were freed. As

\footnotetext{
${ }^{14}$ The reference appears to be to three live births or perhaps to three living children at the time of the next birth. This is even clearer in a will cited in Justinian's Digestum (1.5.15) dealing with the disposition of triplets under a will that freed the molher al the birth of the third child.

${ }^{15}$ Slaves in Baltimore could have had a bit more hope than others. Slaves in this border city were freed with more frequency, although often with a long gap between the decision to manumit and actual freedom (Whitman, 1995).

${ }^{16}$ The calculations were performed by Shawn Cole, Deparıment of Economics, MIT.
} 
in Louisiana, two-thirds of the freed slaves in Brazil and in Rio de Janeiro were women (Mattoso, 1986, 160-65, 177; Karasch, 1987, 346).

Second, the conditions of freedmen. Successful freedmen intensify the incentive for manumission. Freedmen living a marginal existence are still an incentive, since almost all slaves would wish to be free, whatever the economic cost. But the incentive is less than if freedmen are accepted and even prominent. Freedman in the early Roman Empire were citizens; freedmen in the ante-bellum South were not.

Freedmen were ubiquitous in the late Republic and early Empire. They were in all kinds of activities and reached great heights of administration and economic activity (Duff, 1928; Treggiari, 1969). In fact, the number of men who identified themselves on the tombstones in this period as being freedmen is astonishing; they seem to have been proud of this status. Freedmen were fully integrated into the Roman economy, even if not into high Roman society, and their children bore little or no stigma. The success of freedmen was common knowledge; Seneca put down a rich man by remarking that he had the bank account and brains of a freedman (Epistulae Morales, 27.5). Finley remarked, "The contrast with the modern free Negro is evident (Finley, 1980, 98)." Freed slaves in the ante-bellum United States lived a poor existence as Finley suggested. They were not accepted into the mainstream of American life, as they would not be for another century. They were free, but neither prosperous nor highly visible within the larger society. The infamous Dred Scott decision of the United States Supreme Court in 1857 decreed that freed slaves, that is, freed blacks, could not be citizens and "had no rights which the white man was bound to respect (Dred Scott v. Sanford, 60 U.S. 393, 407 (1857)." Freed slaves in Brazil lived a similarly marginal 
existence, not quite slaves, but hardly fully free people either (Mattoso, 1986, 179-83;

Karasch, 1987, 362). ${ }^{17}$

Third, the education of slaves. Educated slaves show a prevalence of positive incentives; uneducated slaves, negative incentives. Roman slaves often were educated; it was illegal to educate American slaves. There were many educated Roman slaves, whom we know as administrators, agents, and authors. For example, Q. Remmius Palaemon was educated in the first century CE ostensibly "as a result of escorting his owner's son to and from school (Bradley, 1994,35)." But one does not get educated by acting as a paedagogus; someone helped this young slave acquire an education. In the Republic, Cato educated slaves for a year and then sold them in a sort of primitive business school (Plutarch, Cato the Elder, 21). Anyone who tried that with modern American slaves would not be celebrated; he would be ostracized, jailed and fined. The Virginia Code of 1848 was clear and extended to freedmen as well as slaves: "Every assemblage of Negroes for the purpose of instruction in reading or writing shall be an unlawful assembly... If a white person assemble with Negroes for the purpose of instructing them to read or write, he shall be confined to jail not exceeding six months and fined not exceeding one hundred dollars (Va. Code [1848], 747-48)." 18

Fourth, occupations. Rome was a thriving metropolis, and the richest Romans were rich indeed. Many different occupations were employed to meet the demands of urban residents, particularly rich ones. There were many free merchants and craftsmen, and there were many skilled slaves. In fact, skilled slaves were valuable to merchants and rich people because they could act as their agents, in the same way as their sons:

\footnotetext{
${ }^{17}$ The marginalization of freedpersons in North and South America demonstrales clearly that slavery in these areas was a closed system, in contrası to the open system of the early Roman Empire.
} 
"Whatever children in our power and slaves in our possession receive by manicipatio or obtain by delivery, and whatever rights they stipulate for or acquire by any other title, they acquire for us (Gaius, Inst. 2.87)." Watson $(1987,107)$ expressed surprise that the Romans did not develop a law of agency, but the Romans did have a law of agency; it was the law of slavery (and sons). Slavery was the only formal, legally enforceable longterm labor contract in the early Roman Empire, as Hicks (1969) noted. A person with a long-term relation to a principal would be his or her most responsible agent. Hence slaves were more valuable than free men as commercial agents, as shown by the frequent references to literate, skilled slave agents in the surviving sources. ${ }^{19}$

Columella (1.8.1-2) exposed the contrast between ancient and modern slavery colorfully: "So my advice at the start is not to appoint an overseer from that sort of slaves who are physically attractive and certainly not from that class which has busied itself with the voluptuous occupations of the city." 20 This warning would not and could not be made about modern slavery, both because modern slaves could not indulge in "voluptuous occupations" like Columella's list of theatre, gambling, restaurants, etc., and because it is inconceivable that a modern slave could have been appointed as manager of a substantial estate.

Fogel and Engerman argued that American slave owners created positive incentives for their slaves in the form of short-term rewards and long-term career advancement "within the social and economic hierarchy that existed under bondage (Fogel and Engerman, 1974, 149)." Such advancement was much diminished relative to

\footnotetext{
${ }_{18}^{18}$ Education does not even appear in the index to Fogel and Engerman, 1974.

${ }^{19}$ Free people also were used as agents, and Roman jurists began to correct the legal discrepancy between free and slave agents in the Principate (Johnson, 1999, 106).
} 
the education and reasonable expectation of manumission of Roman slaves. In addition, Fogel and Engerman greatly overestimated the proportion of American slaves holding even semi-skilled jobs. Research conducted in response to their book showed that virtually all male slaves (97 percent) were unskilled field hands; Fogel and Engerman's assertion that one-quarter of them held a more skilled job was not sustainable (Gutman, 1975; David, et al., 1976). It follows that positive incentives in American slavery were far outweighed by negative ones. There are myriad examples of skilled slaves in the early Roman Empire, but no comparable examples in the ante-bellum United States. Skilled occupations show a prevalence of positive incentives; unskilled occupations, negative incentives.

Implicit in Columella's advice is the ease with which slaves could change jobs. For example, when Horace was given an estate on which he employed five free tenants and nine household slaves, he employed a vilicus from an urban household with no apparent training in agriculture (Aubert, 1994, 133). The mobility of labor must have been even more pronounced for free labor. The demand for unskilled and semi-skilled labor for particular kinds of work varied widely over time both in the country and in the city. Agricultural demand varied seasonally, and the peak rural labor demand was satisfied by temporary employment of free workers in the late Republic and undoubtedly at other times as well (Garnsey, 1998, 143-45). Urban labor demand varied less frequently, but possibly more widely. Public building activity in the Principate varied greatly over time, and workers must have been attracted to these projects one way or another. The presumption is that these were free workers attracted by the wages paid to

\footnotetext{
${ }^{20}$ Igitur praemoneo ne vilicum ex eo genere servorum, qui corpore placuerumt, instituamus, ne ex eo quidem ordine, qui urbanes ac delicates anes exercuerit.
} 
them (Brunt, 1980; Thornton and Thornton, 1989). If so, they also must have been engaged in some other activity to support themselves and their families when public building activity was low.

Fifth, wage dispersion. This is the direct test for existence of a labor market, but the data are not abundant for the Roman period, which is why the indirect tests above have been used. For example, Egyptian wages appear to have doubled after a major plague in 165-75 CE, the Antonine plague (Duncan-Jones, 1996, 124). This clearly is the standard labor-market response to a sharp decrease in the supply of labor. It demonstrates that wages in the early Roman Empire moved to clear markets, in this case to allocate newly scarce labor. Cuvigny (1996) reported that wages of quarry workers appeared to be the same in Egypt and Dacia. This may be no more than a coincidence, but it reveals that workers were paid wages in different parts of the early Roman Empire and that these wages may not have been very different from one place to another. While undoubtedly not identical, still the same order of magnitude.

While not wages, employment contracts give evidence of labor-market activity in which workers could choose their jobs. The modern division between wages and salaries even finds its analogue in Roman Egypt: "As a general rule permanent employees of the Appianus and related estates can be distinguished by their receipt of opsonion (salary), a fixed monthly allowance of cash and wheat and sometimes vegetable oil, whereas occasional employees received misthos, that is 'wages' (Rathbone, 1991, 91 92)." Some of these "free" workers were tied to the estate for life, like more modern serfs, but others were free to leave when their jobs were done. 
There also were employment contracts for miners and apprentices, but the largest group of free workers was farmers. Many of them were tenant farmers, although we should remember that employment categories in the countryside were quite fluid (Garnsey, 1998, 139). Roman tenancy contracts allocated risks between landowners and tenants in very much the same way as analogous contracts did in $18^{\text {th }}$ and $19^{\text {th }}$ century England (Kehoe, 1997). Major risks were borne by the land-owners as events beyond the tenants' control, while minor risks were borne by the tenant in return for the opportunity to earn more and keep his earnings:

Force majeure ought not cause loss to the tenant, if the crops have been damaged beyond what is sustainable. But the tenant ought to bear loss which is moderate with equanimity, just as he does not have to give up profits which are immoderate. It will be obvious that we are speaking here of the tenant who pays rent in money; for a share-cropper (partiarus colonus) shares loss and profit with the landlord, as it were by law of partnership (Gaius, D. 19.2.25.6, quoted in Johnston, 1999, 64).

We know a lot more about wages in England before industrialization. Wages for comparable work were similar throughout England, but they were not uniform.

Agriculture was more prosperous in the South than in the North, and wages were higher in the eighteenth century. (This pattern was reversed in the ninetecnth century when the North industrialized.) There also was substantial variation within regions, due to the immobility of the population (Woodward, 1995). A recent summary of the English data shows winter daily wages in the North to be only half of what they were in the South in 1700. They approached each other gradually over the next century and a half (Clark, $2001,485)$.

England is much smaller than the Roman Empire was. A proper comparison might be between England and Italy. But if we use Roman data from Egypt and Dacia, the proper comparison is with pre-industrial Europe. Clearly, there was even less 
mobility of labor between countries than within England, and wages varied more. They did however remain at the same general level. Allen (forthcoming) demonstrated that wages within Europe began to diverge in the sixteenth and seventeenth centuries. The real wages of masons in London and Antwerp by 1700 were more than double those in other European cities.

This is the standard against which to measure the distribution of wages in the Roman Empire. Based on this more modern evidence, we do not expect to find wages that are equal in distant places except by coincidence, but we expect to find similar wages. If the preceding argument is correct, and there was a labor market in the early Roman Empire that functioned about as well as the labor market in pre-industrial Europe, then wages in the early Roman Empire would have been approximately equal. Wages for similar tasks might have varied by a factor of two or three, as wages did in eighteenth century Europe, but they were not different orders of magnitude. This presumption is consistent with the very fragmentary evidence we have about wages in the Principate.

\section{Conclusion}

There was a functioning labor market in the early Roman Empire where workers typically could change jobs in response to market-driven rewards. As in all agricultural economies, the labor market worked better in cities than in the countryside. Slaves were part of this system with less ability to respond, but with every incentive to respond to the best of their ability. The restrictions on labor mobility may not have been more severe than the restrictions on labor mobility in early modern Europe. Education was the key to good jobs and the good life in the early Roman Empire as it is today. Labor that was 
responsive to economic incentives in the form of payments for their services and largely able to respond to these incentives is a hallmark of Gesellschaft.

"The Roman lawyer Gaius wrote that the fundamental social division was that between slave and free (Garnsey, 1998, p. 134, citing Inst. 1.9)." The fundamental economic division, however, was between educated and uneducated, skilled and unskilled, not between slave and free. Saller $(2000,835)$ summarized this view succinctly: "The disproportionately high representation of freedmen among the funerary inscriptions from Italian cities reflects the fact that ex-slaves were better placed to make a success of themselves in the urban economy than the freeborn poor: upon manumission many of the ex-slaves started with skills and a business."

In summary, there was a market for the services of people in the early Roman Empire, just as there was a market for goods (Temin, 2001). The economy of the early Roman Empire was dominated by Gesellschaft, particularly in the urban environment of Rome itself, although Gemeinschaft was not absent, as it is not absent even today. The market activities that we see in the surviving sources were not marginal activities grafted onto a traditional society; they were the stuff of ordinary life. Gesellschaft did not dominate society for the first time in the nineteenth century, although it may well have become more dominant than it was in the immediately preceding centuries. 


\section{Bibliography}

Allen, Robert, "The Great Divergence: Wages and Prices in Europe from the Middle Ages to the First World War," Explorations in Economic History, forthcoming. Aubert, Jean-Jacques, Business Managers in Early Roman Empire (Leiden: Brill, 1994).

Bagnall, Roger S., and Bruce W. Frier, The Demography of Roman Egypt (Cambridge: Cambridge University Press, 1994).

Bender, Thomas, Community and Social Change in America (New Burnsick, NJ: Rutgers University Press, 1978).

Borhas, George J., "Does Immigration Grease the Wheels of the Labor Market?" Brookings Papers on Economic Activity 1 (2001), 69-133.

Bradley, Keith R., Slaves and Masters in the Roman Empire (New York: Oxford University Press, 1987).

Bradley, Keith R., Slavery and Rebellion in the Roman World, 140 B.C. - 70 B.C. (Bloomington, IN: Indiana University Press, 1989).

Bradley, Keith R., Slavery and Society at Rome (Cambridge: Cambridge University Press, 1994).

Brunt, P. A., "Conscription and Volunteering in the Roman Imperial Army," Scripta Classica Israelica, 1 (1974), 90-115.

Brunt, P. A., "Free Labour and Public Works at Rome," Joumal of Roman Studies, 70 (1980), 81-100.

Clark, Gregory, "Farm Wages and Living Standards in the Industrial Revolution: England, 1670-1850," Economic History Review, 54 (August 2001), 477-505. 
Crook, John A., Law and Life of Rome (London: Thames \& Hudson, 1967).

Cuvigny, Helene, "The Amount of Wages Paid to the Quarry-Workers at Mons Claudianus," Joumal of Roman Stndies, 86 (1996), 139-45.

David, Paul A., et al., Reckoning with Slavery: A Critical Study in the Quantitative History of American Negro Slavery (New York: Oxford University Press, 1976).

Duff, A. M., Freedmen in the Early Roman Empire (Oxford: Oxford University Press, 1928).

Duncan-Jones, R. P., "The Impact of the Antonine Plague," Joumal of Roman Archeology, 9 (1996), 108-36.

Fenoaltea, Stefano, "Slavery and Supervision in Comparative Perspective: A Model," Journal of Economic History, 44 (1984), 635-68.

Findlay, Ronald, "Slavery, Incentives, and Manumission: A Theoretical Model," Joumal of Political Econony, 83 (1975), 923-34.

Finley, Moses, Ancient Slavery and Modem Ideology (London: Chatto and Windus, 1980).

Fogel, Robert W., and Stanley L. Engerman, Time on the Cross: The Economics of American Negro Slavery (Boston: Little, Brown, 1974).

Galenson, David W., White Servitude in Colonial America (Cambridge: Cambridge University Press, 1981).

Garnsey, Peter, Ideas of Slavery from Aristotle to Augustine (Cambridge: Cambridge University Press, 1996). 
Garnsey, Peter, Cities, Peasants and Food in Classical Antiquity (Cambridge: Cambridge University Press, 1998).

Gibbon, Edward, The Decline and Fall of the Roman Empire (New York: Modern Liberary, 1961).

Gutman, Herbert G., Slavery and the Numbers Game: A Critique of Time on the Cross (Urbana: University of Illinois Press, 1975).

Hall, Gwendolyn, Databases for the Study of Afro-Louisiana History and Genealogy, 1699-1860 (New Orleans: Louisiana State University Press, 2000).

Harris, John R., and Michael P. Todaro, "Migration, Unemployment and Development: A Two-Sector Analysis," American Economic Review, 60 (1970), 126-42.

Harris, W. V., "Demography, Geography and the Sources of Roman Slaves," Journal of Roman Studies, 89 (1999), 62-75.

Hicks, John, A Theory of Economic History (Oxford: Oxford University Press, 1969).

Hopkins, Keith, Conquerors and Slaves (Cambridge: Cambridge University Press, 1978).

Johnston, David, Roman Law in Context (Cambridge: Cambridge University Press, 1999).

Jones, A. H. M., "The Economics of Slavery in the Ancient World," Economic History Review, 9 (1956), 185-204.

Karasch, Mary C., Slave Life in Rio de Janeiro, 1808-1850 (Princeton: Princeton University Press, 1987). 
Kehoe, Dennis P. Investment, Profit, and Tenancy: The Jurists and the Ronnan Agrarian Economy (Ann Arbor: University of Michigan Press, 1997).

Mattoso, Katia M. de Queiros, To Be a Slave In Brazil, 1550-1888 (New Brunswick, NJ: Rutgers University Press, 1986).

Polanyi, Karl, The Great Transformation (New York: Holt, Rinehart and Winston, 1944).

Ramin, Jacques, and Paul Veyne, "Droit Romain et Societe; les Hommes Libres qui Passent pour Esclaves et l'Esclavage Volontaire," IIistoria, 30 (4), 472-97 (1981).

Rathbone, Dominic, Economic Rationalism and Rural Society in Third Century A.D. Egypt (Cambridge: Cambridge University Press, 1991).

Saller, Richard, "Status and Patronage," in Alan K. Bowman, Peter Garnsey and Dominic Rathbone (eds.), The Cambridge Ancient History, Second Edition, Vol. XI, The High Empire, A.D. 70-192 (Cambridge: Cambridge University Press, 2000), 817-54.

Scheidel, Walter, "Quantifying the Source of Slaves in the Early Roman Empire," Joumal of Roman Studies, 87 (1997), 157-69.

Scheidel, Walter, "Progress and Problems in Roman Demography," in Walter Scheidel (ed.), Debating Roman Demograply (Leiden: Brill, 2001), 1-81.

Taylor, Lilly Ross, "Freedmen and Freeborn in the Epitaphs of Imperial Rome," American Journal of Philology, 82 (2), 113-32 (1961).

Temin, Peter, "A Market Economy in the Early Roman Empire," Joumal of Roman Studies, 91 (2001), 169-81.

Thornton, M. K., and R. L. Thomton, Julio-Claudian Building Programs (Wauconda, IL: Bolehazy-Carducci, 1989). 
Toennies, Gemeinschaft und Gesellschaft (1887), translated by Charles P. Loomis as Comnnunity and Society (East Lansing, MI: Michigan State University Press, 1957).

Treggiari, Susan, Roman Freedmen during the Late Republic (Oxford: Oxford University Press, 1969).

Watson, Alan, Roman Slave Law (Baltimore: Johns Hopkins University Press, 1987).

Watson, George R., The Roman Soldier (Ithica, NY: Cornell University Press, 1969).

Watson, James L., "Slavery as an Institution, Open and Closed Systems," in James L. Watson (ed.), Asian and African Systems of Slavery (Oxford: Blackwell, 1980).

Weaver, P. R. C., Familia Caeseris: A Social Study of the Emperor's Freedmen and Slaves (Cambridge: Cambridge University Press, 1972).

Weber, Max, The Protestant Ethic and the Spirit of Capitalism 1905).

Whitman, Stephen, "Diverse Good Causes: Manumission and the Transformation of Urban Slavery," Social Science History, 19 (1995), 333-70.

Woodward, Donald, Men at Work: Labourers and Building Craftsmen in the Towns of Northern England, 1450-1750 (Cambridge: Cambridge University Press, 1995). Zimmern, Alfred, "Was Greek Civilization Based on Slave Labor?" Sociological Review, 2 (1909), 1-19, 159-76; reprinted in Alfred Zimmern, Solon and Croesus (London: Oxford University Press, 1928). 






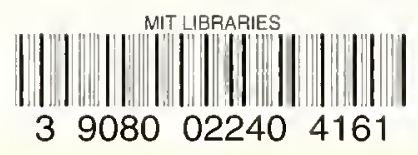


2.

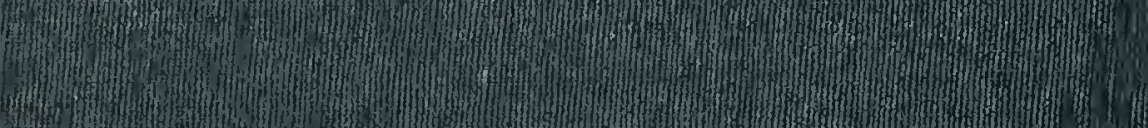

1.7.m.

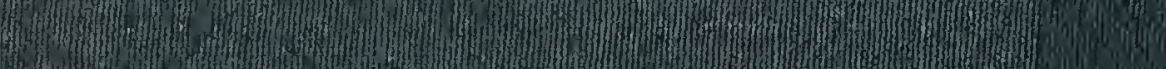

(1) (1)

(3)

7.6.

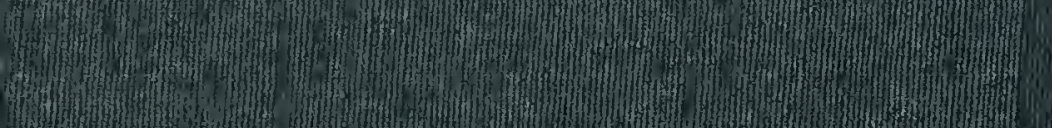

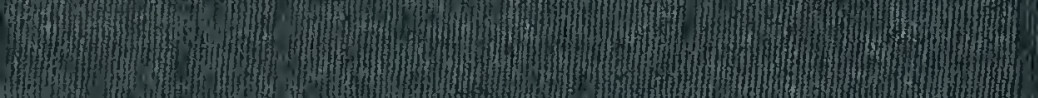

H.

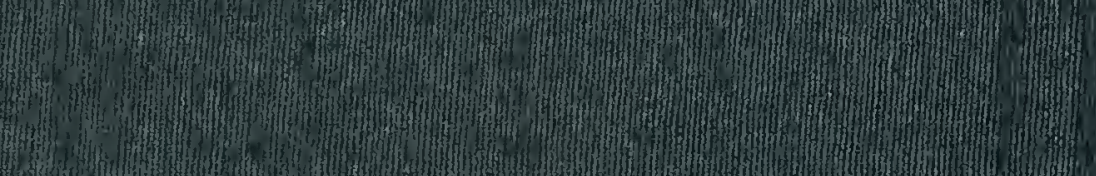

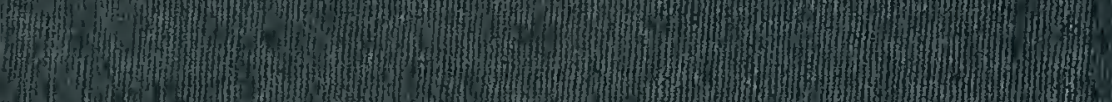

6.7,

9.

H.

ath

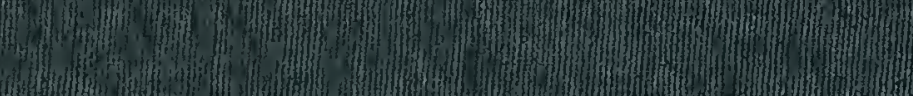

fom

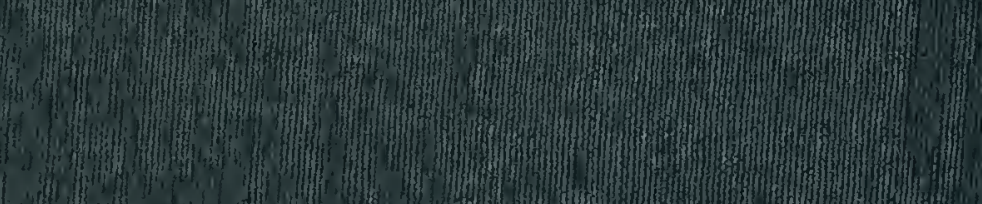

60,

3.

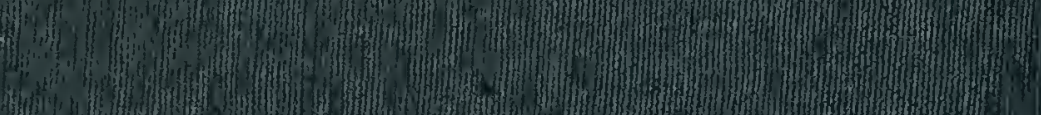

3.th

m.

13.

13.

6.

W.

H.

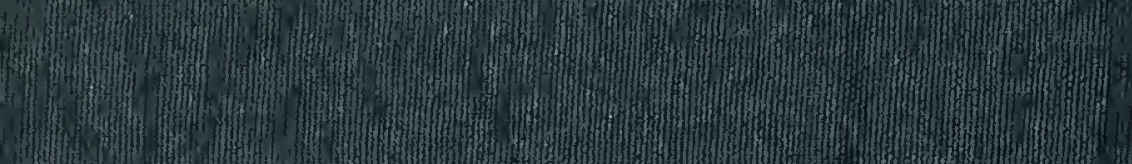

H. H. H.

m-

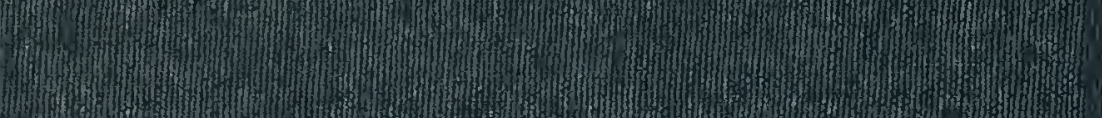
-

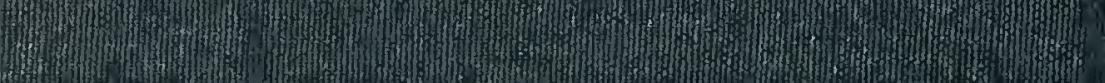

